\title{
SPATIAL AND TEMPORAL VARIABILITY OF SEED BANK RESULTING FROM OVERGROWING OF XEROTHERMIC GRASSLAND
}

\author{
JOANNA CZARNECKA \\ Ecology Department, Institute of Biology, Maria Skłodowska-Curie University \\ Akademicka 19, 20-033 Lublin, Poland \\ e-mail: a_czarnecki@wp.pl
}

(Received: March 2, 2007. Accepted: October 4, 2007)

\begin{abstract}
The aim of my study was to determine changes in the seed bank and vegetation during the process of overgrowing of the xerothermic grassland situated on the slopes of the White Mountain ( $349 \mathrm{~m}$ a. s. 1., the Central Roztocze Region, South-Eastern Poland). I also examined whether the changes of vegetation can be predicted if we know the structure of the burned seed flora. To achieve this goal I used two sets of data: one collected from three different environments (grassland, brushwood and woodland) at the same time (toposequence), and the other collected twice from the same place at the interval of seven years (chronosequence). I stated that the appearance of even a small number of ornitochorous seeds and their seedlings can be treated as a signal that the bush encroachment will accelerate. Seed number seems to decrease during succession in the analysed sequence of plant communities. The total number of species in the seed bank did not change in the most dynamic plant communities: grassland and brushwood, and it was significantly higher there than in the seed bank of woodland. During the time of observation, the most important quantitative and qualitative changes took place in grassland vegetation, which is more similar to brushwood vegetation now than it was at the beginning of the study.
\end{abstract}

KEY WORDS: xerothermic grassland, succession, bush encroachment, seed bank.

\section{INTRODUCTION}

Xerothermic grasslands are one of the most species-rich habitats, both on a small spatial scale (less than $1 \mathrm{~m}^{2}$ ), and on a large, habitat scale (WallisDeVries et al. 2002). This is the reason why they are a central issue in natural conservation management in whole Europe (Willems 1983; Bobbink and Willems 1987; Poschold and WallisDeVries 2002). These plant communities are mainly semi-natural, originating after felling of primeval forests by men already in prehistoric times and later. They reached their maximum spread between the 15th and 20th century (Poschold and WallisDeVries 2002; WallisDeVries et al. 2002). The area of calcareous grasslands in Europe dramatically decreased mainly due to changes in land use and eutrophication during the last decades. Abandonment of traditional land use (grazing by sheep or cattle, mowing) followed by successional changes of vegetation are the main threat for these type of habitat. Bush encroachment and the increase in dominance of competitive grasses, mainly Brachypodium pinnatum, are the most important successional changes responsible for reduction of floristic diversity of xerothermic grasslands (Bobbink and Willems 1987; Bakker et al. 1996; Schlaepfer 1997; Dzwonko and Loster 1992, 1998;
Hurst and John 1999; Babczyńska-Sendek 2004; Loster and Gawroński 2005). They are also strongly fragmented now, and threatened by extinction and inbreeding of remaining populations (WallisDeVries et al. 2002).

Special management programmes must be developed for these sites to maintain their floristic richness (Willems 1983). There are many studies testing the effectiveness of different management regimes for the maintenance or restoration of grasslands (e.g. Willems 1983, Milberg 1995; Schlaepfer 1997; Dzwonko and Loster 1998; Bąba 2003), but studies analysing the structure and changes of the seed bank accompanying the "vegetation turnover" are still quite rare (Milberg and Hansson 1994). Seed bank may play a significant role in the gap regeneration and the determining of future species composition of plant communities (Rusch and van der Maarel 1992; Kalamees and Zobel 1997, 2002). The composition of the seed bank is not only a reflection of surface vegetation but also a record of the history of its changes (Grandin and Rydin 1998; Falińska 1999).

According to some authors, restoration management of grassland communities cannot rely on the seed bank. Poor correspondence between buried seed flora and vegetation composition in grassland communities was observed (e.g. 
TABLE 1. Vegetation characteristic of the study area.

\begin{tabular}{|c|c|c|c|c|c|c|}
\hline \multirow[b]{2}{*}{ Year } & \multicolumn{2}{|c|}{ Grassland } & \multicolumn{2}{|c|}{ Brushwood } & \multicolumn{2}{|c|}{ Woodland } \\
\hline & 1999 & 2005 & 1999 & 2005 & 1999 & 2005 \\
\hline Relevé number & 1 & 2 & 3 & 4 & 5 & 6 \\
\hline Area $\left(\mathrm{m}^{2}\right)$ & 400 & 400 & 75 & 75 & 400 & 400 \\
\hline Gradient of the slope & 10 & 10 & 20 & 20 & 10 & 10 \\
\hline Number of species in the record & 49 & 55 & 48 & 46 & 24 & 28 \\
\hline \multicolumn{7}{|l|}{ 1. All. Cirsio-Brachypodion pinnati } \\
\hline Aster amellus L. & + & 1 & & 1 & & \\
\hline 2. O. Festucetalia valesiacae & + & + & & & & \\
\hline Scabiosa ochroleuca $\mathrm{L}$. & 1 & 2 & 1 & 1 & & \\
\hline \multicolumn{7}{|l|}{ Salvia verticillata $\mathrm{L}$. } \\
\hline & + & + & & & & \\
\hline 3. Cl. Festuco-Brometea & 1 & 2 & + & & & \\
\hline Plantago media $\mathrm{L}$. & + & 1 & 1 & 2 & & \\
\hline Brachypodium pinnatum (L.) P. Beauv. & + & + & 1 & 3 & & \\
\hline Teucrium chamaedrys L. & 3 & 4 & 1 & 3 & & \\
\hline
\end{tabular}

Euphorbia cyparissias L.

Carex flacca Schreb. (lok.)

Sporadic species: Centaurea scabiosa L. 1, Carlina vulgaris L. 1, Poa compressa L. 1

4. All. Geranion sanguinei

Trifolium alpestre $\mathrm{L}$.

Fragaria viridis Duchesne

$2++$

5. O. Origanetalia

Galium verum $\mathrm{L}$.

Origanum vulgare L.

Agrimonia eupatoria $\mathrm{L}$.

Clinopodium vulgare $\mathrm{L}$.

Sporadic species: Coronilla varia L. 1, Astragalus cicer L. 5, Astragalus glycyphyllos L. 1

6. All. Arrhenatherion elatioris

O. Arrhenatheretalia*

Galium mollugo L.*

Dactylis glomerata L.*

Leucanthemum vulgare Lam.*

Tragopogon orientalis $\mathrm{L}$.

Geranium pratense L.

Knautia arvensis (L.) J. M. Coult.*

Achillea millefolium L.*

Taraxacum officinale F. H. Wigg.*

Sporadic species: Crepis biennis L. 3

7. All. Molinion caeruleae

Galium boreale L.

8. Cl. Molinio-Arrhenatheretea

Festuca pratensis Huds.

Leontodon hispidus L.

Vicia cracca $\mathrm{L}$.

Ranunculus acris L.

Sporadic species: Prunella vulgaris L. 2

9. Cl. Rhamno-Prunetea

Prunus spinosa L. b

Rosa sp. b

Crategus monogyna Jacq. b

Viburnum opulus L. b

Prunus spinosa L. c

Cornus sanguinea L. b

Cornus sanguinea L. c

Crategus monogyna Jacq. c

Viburnum opulus L. c

Rhamnus cathartica L. c

Sporadic species: Rosa sp. c 1 
TABLE 1. Cont.

\begin{tabular}{|c|c|c|c|c|c|c|}
\hline \multirow[b]{2}{*}{ Year } & \multicolumn{2}{|c|}{ Grassland } & \multicolumn{2}{|c|}{ Brushwood } & \multicolumn{2}{|c|}{ Woodland } \\
\hline & 1999 & 2005 & 1999 & 2005 & 1999 & 2005 \\
\hline Relevé number & 1 & 2 & 3 & 4 & 5 & 6 \\
\hline Area $\left(m^{2}\right)$ & 400 & 400 & 75 & 75 & 400 & 400 \\
\hline Gradient of the slope & 10 & 10 & 20 & 20 & 10 & 10 \\
\hline Number of species in the record & 49 & 55 & 48 & 46 & 24 & 28 \\
\hline
\end{tabular}

10. O. Quercetalia pubescenti-petraeae

D. Vincetoxicum hirundinaria Medik.

11. O. Fagetalia sylvaticae

Cl. Querco-Fagetea*

Lonicera xylosteum L. c*

Brachypodium sylvaticum (Huds.) P. Beauv.*

Cerasus avium (L.) Moench c

Cerasus avium (L.) Moench b

Viola reichenbachiana Jord. ex Boreau

Melica nutans L.*

Hepatica nobilis Schreb.*

Epipactis helleborine (L.) Crantz

Viola mirabilis $\mathrm{L}$.

Corylus avellana L. b*

Carex digitata $\mathrm{L} . *$

Campanula trachelium $\mathrm{L}$.

Asarum europaeum L.

Carpinus betulus L. c

Carpinus betulus L. b

Actaea spicata $\mathrm{L}$.

Carpinus betulus L. a

Fagus sylvatica L. a

Aegopodium podagraria L.*

Sporadic species: Anemone nemorosa L. 3, Acer platanoides L.* 4, Acer pseudoplatanus L. b 2

12. Companion species

Verbascum nigrum $\mathrm{L}$.

Tussilago farfara $\mathrm{L}$.

Cruciata glabra (L.) Ehrend.

Pinus sylvestris L. b

Senecio macrophyllus M. Bieb.

Pimpinella saxifraga $\mathrm{L}$.

Valeriana officinalis L.

Hypericum perforatum $\mathrm{L}$.

Anthriscus sylvestris (L.) Hoffm.

Pinus sylvestris L. a

Ajuga reptans $\mathrm{L}$.

Frangula alnus Mill. b

Medicago lupulina L.

Solidago virgaurea $\mathrm{L}$.

Cichorium intybus L.

Salix caprea L.

Rubus caesius L.

Padus avium Mill. b

Sorbus aucuparia L. em. Hedl. b

Sorbus aucuparia L. em. Hedl. c

Hedera helix L.

Convallaria majalis $\mathrm{L}$.

Maianthemum bifolium (L.) F. W. Schmidt

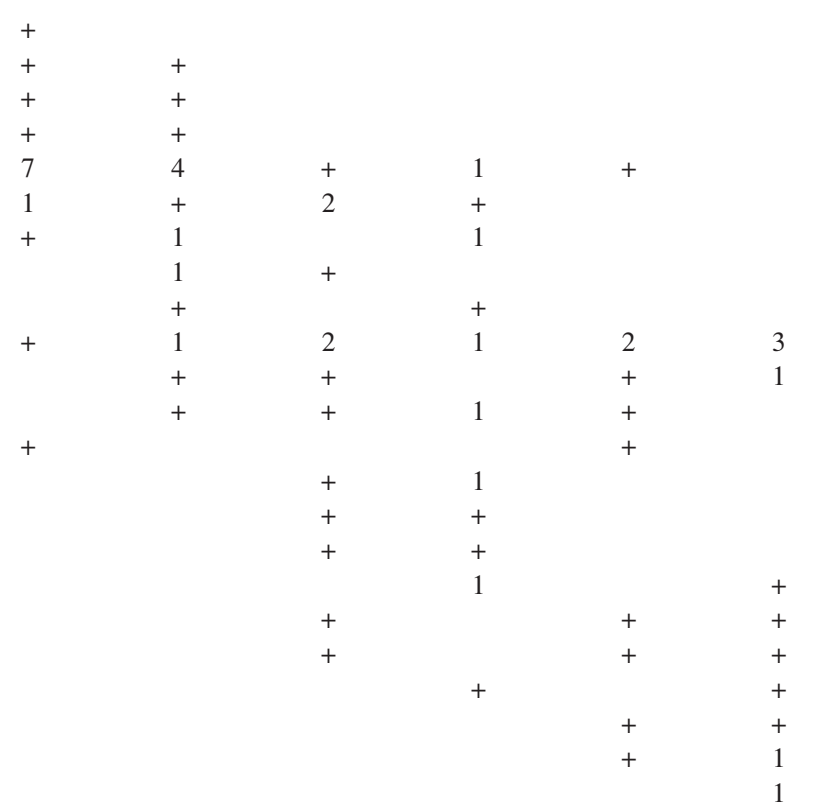

Sporadic species: Alchemilla monticola Opiz 3, Calamagrostis epigejos (L.) Roth 1, Carex transsilvanica Schur 1, Frangula alnus Mill. c 4, Glechoma hederacea L. 3, Hieracium umbellatum L. 3, Linum catharticum L. 1, Rubus idaeus L. 5, Rubus plicatus Weihe \& Nees 6, Quercus robur L. b 4, Erigeron annuus (L.) Pers. 2, Picris hieracioides L. 2, Sambucus nigra L. b 6

Schenkeveld and Verkaar 1984). In Swedish grasslands changes in above- and below-ground flora were similar, and in most cases the species lost from the growing vegetation could not be found in the bank, either (Milberg 1992, 1995). Most grassland species were classified as having a short-term persistent or transient seed bank (Bakker et al. 1996), and the rege- neration of grasslands after disturbances is often dominated by regrowth from vegetative parts there (Milberg 1993).

Until now most studies of seeds in the soil have concentrated on seed bank size, species composition and germination requirements. They have not considered the dynamic nature of the seed bank (Hyatt and Casper 2000). Accor- 
ding to Falińska (1999), long term simultaneous research on the dynamics of above- and below-ground vegetation is needed. It may help to understand the complex relations between species composition changes in space and time.

This study is the next work analysing the seed bank of xerothermic grassland situated on The White Mountain in the Central Roztocze Region (Czarnecka J. and Czarnecka B. 2001; Czarnecka J. 2004a, b, 2005). The novelty of my study and the main aim of it was to determine changes in the seed bank and vegetation during the process of bush encroachment on xerothermic grassland. I also asked if the changes of vegetation can be predicted if we know the composition of the buried seed flora. I tested two hypotheses (Milberg 1995): (1) species richness in the soil bank decreases during succession; (2) the density of buried seeds declines during succession. In Milberg's work (1995) both of them came out to be false and I decided to check if it is a rule in this type of community. To achieve this goal I used and compared two sets of data: one collected from three different environments (grassland, brushwood and woodland) at the same time (toposequence or space-for time substitution, according to Pickett 1989), and the other collected twice from the same place at the interval of seven years (chronosequence).

\section{MATERIAL AND METHODS}

\section{Study site}

The study area was located on the White Mountain, a hill of altitude $349 \mathrm{~m}$ a. s. 1., situated in South-Eastern Poland in the Central Roztocze Region $\left(50^{\circ} 28^{\prime} \mathrm{N}, 23^{\circ} 29^{\prime} \mathrm{E}\right)$. Its soils consist mainly of Cretaceous marls and loess. Creataceous rendzinas of medium nutrient availability are formed here. The litter level is very shallow (up to a few centimetres) and the thickness of humus horizon is about $10-15 \mathrm{~cm}$ (Czarnecka B. 1995). The largest part of the southern and south-western slopes are overgrown with xerothermic grassland of the alliance Cirsio-Brachypodion pinnati Hadač et Klika 1944 (Czarnecka B. 1994). The detailed site description was done shortly later (Czarnecka B. 1995; Czarnecka J. 2004a, 2005).

The border between the grassland and the woodland is formed by a brushwood of the Rhamno-Prunetea Rivas Goday et Garb. 1961 class. This brushwood (with the dominance of Prunus spinosa and Cornus sanguinea) forms a belt of vegetation adjacent to the woodland, which is dominated by Carpinus betulus, and also contains Fagus sylvatica, Populus tremula, Tilia cordata, Betula pendula and Pinus sylvestris (Czarnecka B. 1995).

The grassland is burnt sometimes (once every few years). The process of bush encroachment is relatively slow there: the main factor hampering it is probably, apart of fire, drought killing all newly established seedlings. Brushwood development is more dynamic in more humid parts of grasslands, e.g. in small patches situated on the western and north-western slopes of the White Mountain. The dynamics of the process of overgrowing of the grassland was the main reason that the grassland situated on the north-western slope was chosen for study (Fig. 1).

\section{Seed bank study}

The study was carried out in November 1997 and 2004 when the main seed shedding was finished. Three soil sam- ples (100 $\mathrm{ml}$ each, $5 \mathrm{~cm}$ deep, the surface area of one sample was $19.7 \mathrm{~cm}^{2}$ ) per each meter were taken in 1997 , and five per each meter in 2004 along the transect 46 meters long (Fig. 1), which was traced on the north-western slope through the xerothermic grassland $(15 \mathrm{~m})$, brushwood (11 $\mathrm{m})$ and woodland $(20 \mathrm{~m})$. A bigger amount of soil was taken in 2004 to maximise the accuracy of the study. According to Thompson (1986), the minimum number of samples required for a reliable estimation of the seed bank is fifty. Thus, the number of soil cores taken in 2004 guarantees better accuracy of the study even for the brushwood belt, which is the shortest part of the transect. The samples from each particular metre were pooled and mixed. The volume of the soil samples was reduced by washing and sieving (with a sieve diameter of $0.25 \mathrm{~mm}$ ). Then, under the magnification of $10 \times$ all the seeds were picked out and recorded. Species presence in the seed bank was quantified as the mean number of seeds per square meter. During the identification of seeds available literature (Kulpa 1974; Skrzypczak et al. 1997) and collection of seeds from the study area were used.

The seeds classified into five commonly used dispersal modes (e.g. Dzwonko 2001): anemochores - diaspores with wings or plumes and the smallest seeds with no dispersal attributes; barochores - bigger seeds with no dispersal adaptations; endozoochores - fruits with fleshy pulp, which are eaten by vertebrates, mainly by birds; epizoochores - fruits with hooks and hairs which adhere to fur or feathers; myrmecochores - seeds with elaiosomes.

\section{Surface vegetation study}

Three phytosociological relevés in each of the adjacent plant communities (grassland, brushwood and woodland) were done 1999 and 2005 (a year or two after the soil samples were taken, Table 1). Decimal scale with + symbol $(+$ for the species with cover less than 5\%, 1 for cover 5-15\%, $2-15-25 \%, \ldots, 10-95-100 \%$ ) was used.

\section{Data analysis}

The Kruskal-Wallis test was used to check the significance of the differences among the means (mean number of species, mean densities of seeds, mean proportion of different groups of species) calculated for data collected in the same year (independent data) and the Wilcoxon's test was chosen for the data collected from the same place with the interval of seven years (dependent data).

The Detrended Correspondence Analysis (DCA) was used to ordinate surface vegetation and seed bank data and to analyse their variability in space and time. Analyse was conducted with the programme CANOCO 4.5 (ter Braak and Smilauer 2002). Seed bank data and cover of individual species were transformed to a 1-9 scale before the analyses were made (share in the total number of seeds or percentage of abundance in vegetation less than $1 \%-1 ; 1-2 \%$ $-2 ; 2-3 \%-3 ; 3-5 \%-4 ; 5-10 \%-5 ; 10-25 \%-6 ; 25-50 \%-$ $7 ; 50-75 \%-8 ; 75-100 \%-9)$.

\section{RESULTS}

Surface vegetation data were presented in Table 1. Any clear directional changes in the cover of grassland species were observed. The cover of some grassland species 


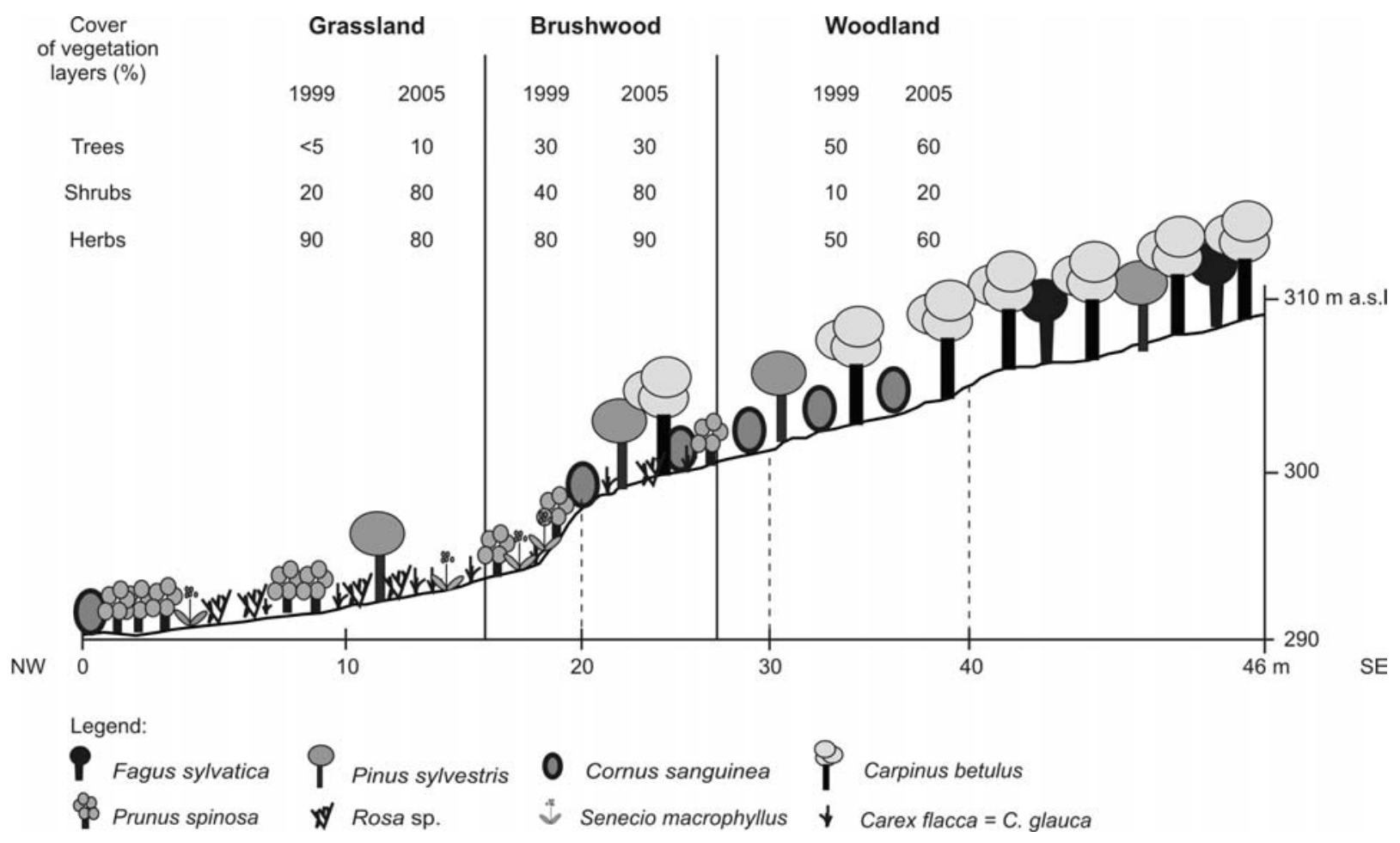

Fig. 1. Scheme of the vegetation composition in the study site (2005).
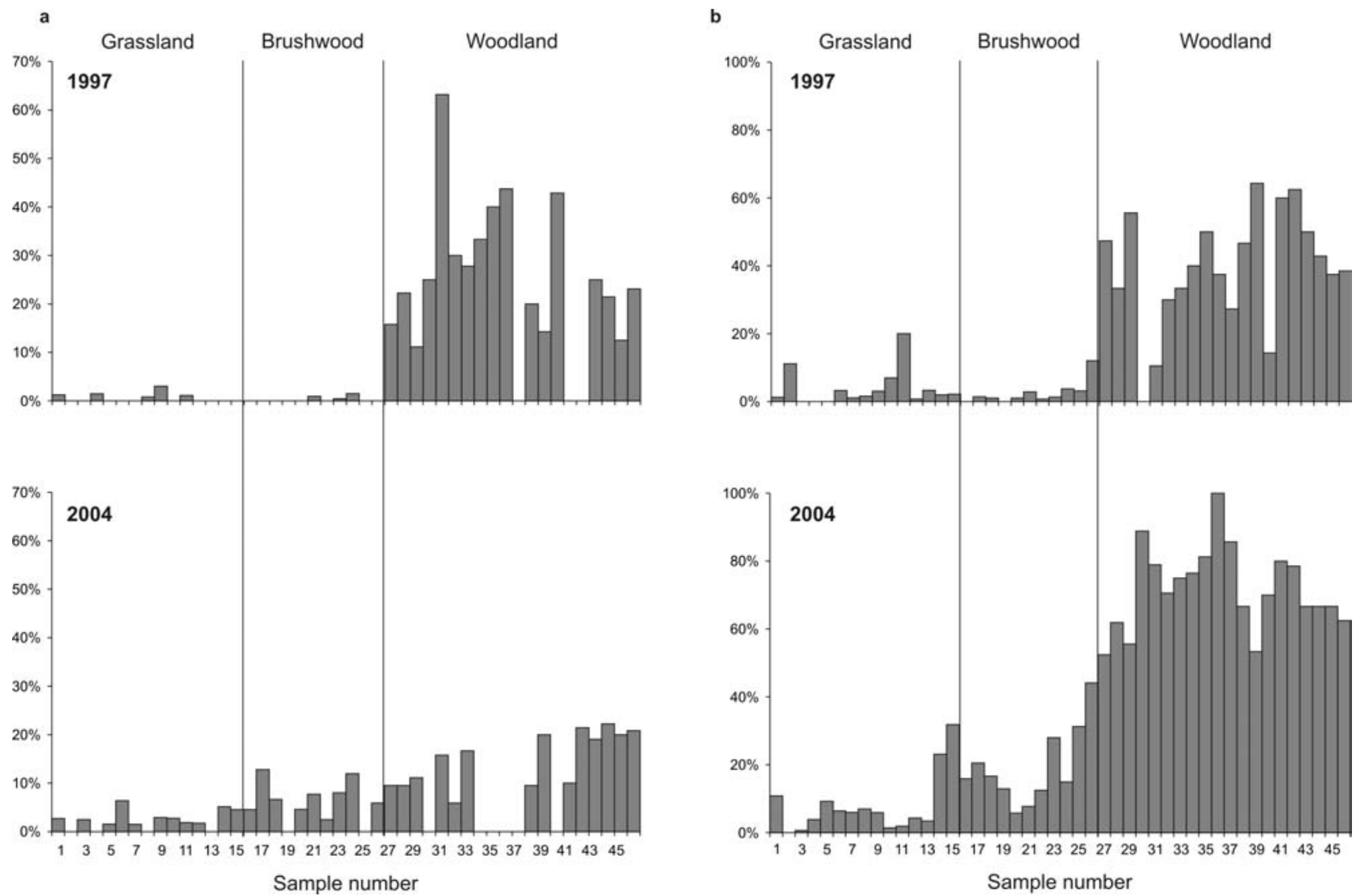

Fig. 2. Distribution of diasporas of brushwood (a) and woodland (b) species in the soil of three adjacent plant communities: grassland, brushwood and woodland.

increased (Agrimonia eupatoria, Carex flacca, Organum vulgare, Picris hieracioides, Salvia verticilata, Teucrium chamaedrys), and the abundance of the others decreased (e.g. Carex transsilvanica, Linum catharticum and Senecio macrophyllus) in the year 2004, in comparison to 1997.
The decrease in the herb layer was usually accompanied by a considerable lowering of the number of seeds in soil (Table 2). The most striking was the increase in the coverage of almost all of the brushwood (shrubs, mainly species characteristic for the class Rhamno-Prunetea) and wood- 
TABLE 2. Composition of the seed bank and vegetation. Life form: T - tree, S - shrub, H - dicotyledonous herb, G - grass or sedge. Dispersal mode: A anemochore, B - barochore, En - endozoochore, Ep - epizoochore, M - myrmecochore. Vegetation data: $\nearrow$ - increase of abundance (data from 2005 compared with data from 1999), $>$ - decrease of abundance, = similar abundance in both seasons, -- absence of species.

\begin{tabular}{|c|c|c|c|c|c|c|c|c|c|c|c|}
\hline \multirow{3}{*}{ Taxon } & \multirow{3}{*}{$\begin{array}{l}\text { Life } \\
\text { form }\end{array}$} & \multirow{3}{*}{$\begin{array}{l}\text { Dispersal } \\
\text { mode }\end{array}$} & \multicolumn{3}{|c|}{ Vegetation changes } & \multicolumn{6}{|c|}{ Seed bank (per square meter) } \\
\hline & & & \multirow{2}{*}{$\begin{array}{l}\text { Grass- } \\
\text { land }\end{array}$} & \multirow{2}{*}{$\begin{array}{l}\text { Brush- } \\
\text { wood }\end{array}$} & \multirow{2}{*}{$\begin{array}{l}\text { Wood- } \\
\text { land }\end{array}$} & \multicolumn{2}{|c|}{ Grassland } & \multicolumn{2}{|c|}{ Brushwood } & \multicolumn{2}{|c|}{ Woodland } \\
\hline & & & & & & 1997 & 2004 & 1997 & 2004 & 1997 & 2004 \\
\hline \multicolumn{12}{|l|}{ Grassland species } \\
\hline Agrimonia eupatoria $\mathrm{L}$. & $\mathrm{H}$ & Ep & 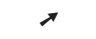 & $\pi$ & - & 11 & - & - & - & - & 5 \\
\hline Carex flacca Schreb. & G & $\mathrm{B}$ & $\lambda$ & $\pi$ & - & 4760 & 2992 & 5780 & 2893 & 17 & 31 \\
\hline Clinopodium vulgare $\mathrm{L}$. & $\mathrm{H}$ & $\mathrm{B}$ & $y$ & $y$ & - & 227 & 95 & 1190 & 37 & 51 & - \\
\hline Coronilla varia $\mathrm{L}$. & $\mathrm{H}$ & $\mathrm{B}$ & $y$ & - & - & 11 & 34 & - & 9 & 17 & - \\
\hline Euphorbia cyparissias L. & $\mathrm{H}$ & M & $=$ & $\pi$ & - & 45 & 7 & 62 & 28 & - & 10 \\
\hline Fragaria viridis Duchesne & $\mathrm{H}$ & En & $=$ & $\pi$ & - & 181 & 88 & 510 & 37 & 43 & 5 \\
\hline Linum catharticum $\mathrm{L}$. & $\mathrm{H}$ & A & $y$ & - & - & 1133 & 20 & 155 & 9 & - & - \\
\hline Origanum vulgare $\mathrm{L}$. & $\mathrm{H}$ & A & $\lambda$ & $=$ & - & 3241 & 782 & 21204 & 668 & 162 & 10 \\
\hline Picris hieracioides L. & $\mathrm{H}$ & A & $\lambda$ & - & - & - & - & 9 & - & - & 5 \\
\hline Senecio macrophyllus M. Bieb. & $\mathrm{H}$ & A & $y$ & $\pi$ & - & 306 & 61 & 15 & 9 & - & - \\
\hline Teucrium chamaedrys L. & $\mathrm{H}$ & $\mathrm{B}$ & 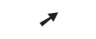 & $\pi$ & - & - & - & 31 & - & 9 & - \\
\hline Thymus pulegioides L. & $\mathrm{H}$ & A & - & - & - & 11 & - & 108 & - & - & - \\
\hline Trifolium alpestre $\mathrm{L}$. & $\mathrm{H}$ & $\mathrm{B}$ & $y$ & $\pi$ & - & 57 & 7 & 15 & 9 & - & 5 \\
\hline
\end{tabular}

Meadow and ruderal species

Calamagrostis epigejos (L.) Roth

Chenopodium album $\mathrm{L}$.

Cirsium arvense (L.) Scop.

Cirsium vulgare (Savi) Ten.

Daucus carota L.

Fallopia convolvulus (L.) Á Löve

Galium mollugo L.

Hieracium sp.

Hypericum perforatum $\mathrm{L}$.

Leucanthemum vulgare Lam.

Medicago lupulina $\mathrm{L}$.

Plantago lanceolata L.

Polygala vulgaris L.

Prunella vulagaris L.

Ranunculus acris $\mathrm{L}$.

Urtica dioica $\mathrm{L}$.

Valeriana officinalis L.

Veronica chamaedrys L.

Verbascum nigrum $\mathrm{L}$.

Vicia cracca $\mathrm{L}$.

\begin{tabular}{|c|c|c|c|c|}
\hline $\mathrm{G}$ & A & $=$ & - & - \\
\hline $\mathrm{H}$ & B & - & - & - \\
\hline $\mathrm{H}$ & A & - & - & - \\
\hline $\mathrm{H}$ & A & - & - & - \\
\hline $\mathrm{H}$ & Ep & - & - & - \\
\hline $\mathrm{H}$ & A & - & - & - \\
\hline $\mathrm{H}$ & A & $\pi$ & $\pi$ & - \\
\hline $\mathrm{H}$ & A & - & $y$ & - \\
\hline $\mathrm{H}$ & A & $\lambda$ & $y$ & - \\
\hline $\mathrm{H}$ & A & $=$ & $y$ & - \\
\hline $\mathrm{H}$ & B & $y$ & - & $y$ \\
\hline $\mathrm{H}$ & A & - & - & - \\
\hline $\mathrm{H}$ & $\mathrm{M}$ & - & - & - \\
\hline $\mathrm{H}$ & B & $\lambda$ & - & - \\
\hline $\mathrm{H}$ & B & $=$ & $\pi$ & - \\
\hline $\mathrm{H}$ & $\mathrm{A}$ & - & - & - \\
\hline $\mathrm{H}$ & A & $\pi$ & $\pi$ & - \\
\hline $\mathrm{H}$ & A & - & - & - \\
\hline $\mathrm{H}$ & $\mathrm{A}$ & $y$ & - & - \\
\hline $\mathrm{H}$ & B & $=$ & $\pi$ & - \\
\hline
\end{tabular}

\begin{tabular}{cccccc}
- & 7 & - & - & - & 10 \\
11 & 7 & - & 19 & 9 & - \\
11 & 7 & 46 & - & 9 & 31 \\
45 & - & 15 & - & 17 & - \\
11 & - & 46 & - & 9 & - \\
34 & - & 77 & - & - & - \\
45 & 27 & 15 & 19 & - & 5 \\
11 & - & - & 9 & - & 5 \\
680 & 1822 & 788 & 269 & 77 & 61 \\
91 & 20 & 46 & - & 9 & - \\
113 & 136 & 124 & 74 & 26 & 56 \\
- & 14 & - & 9 & - & - \\
57 & 27 & - & - & - & - \\
34 & 7 & - & - & - & - \\
57 & 14 & 232 & 28 & - & 10 \\
11 & 7 & 247 & 9 & - & - \\
- & 34 & 9 & 9 & - & - \\
11 & 231 & 155 & 46 & 17 & 25 \\
215 & 75 & 15 & 19 & - & 5 \\
- & 7 & - & 9 & - & 5 \\
\hline
\end{tabular}

Brushwood species

Cornus sanguinea L.

Crategus monogyna Jacq.

Prunus spinosa $\mathrm{L}$.

Rosa sp.

Sambucus sp.

\begin{tabular}{lllllllllll}
$\mathrm{S}$ & $\mathrm{En}$ & $\nearrow$ & $=$ & $\nearrow$ & 11 & 109 & 15 & 130 & 145 & 112 \\
$\mathrm{~S}$ & $\mathrm{En}$ & $\nearrow$ & $\nearrow$ & - & - & 14 & - & 28 & 9 & 10 \\
$\mathrm{~S}$ & $\mathrm{En}$ & $\nearrow$ & $\nearrow$ & - & 11 & - & 15 & 19 & 9 & - \\
$\mathrm{S}$ & $\mathrm{En}$ & $\nearrow$ & $=$ & $\nearrow$ & - & 14 & - & - & - & - \\
$\mathrm{S}$ & $\mathrm{En}$ & - & - & $\nearrow$ & 34 & - & 62 & 93 & 281 & 61 \\
\hline
\end{tabular}

\section{Woodland species}

Ajuga reptans $\mathrm{L}$.

Betula pendula Roth

Campanula trachelium $\mathrm{L}$.

Carex digitata $\mathrm{L}$.

Carpinus betulus L.

Hepatica nobilis Schreb.

Melica nutans L.

Rubus sp.

Viola sp.

$\begin{array}{lll}H & M & \nearrow \\ T & \text { A } & - \\ H & \text { A } & \nearrow \\ \text { G } & \text { M } & \nearrow \\ T & \text { A } & - \\ H & \text { Ep } & \nearrow \\ \text { G } & \text { A } & \nearrow \\ \text { S } & \text { En } & - \\ H & \text { M } & \nearrow\end{array}$

$\begin{array}{ll}x & \\ - & \\ x & \\ = & = \\ = & \\ = & \\ \nearrow & \end{array}$

$\begin{array}{lcccccc}\nearrow & 68 & 20 & 46 & 37 & 119 & 41 \\ - & 385 & 224 & 294 & 223 & 272 & 403 \\ \nearrow & 45 & 27 & 93 & 93 & 9 & 20 \\ = & 408 & 68 & 124 & 176 & 68 & 71 \\ = & 23 & 7 & 155 & 139 & 486 & 332 \\ \nearrow & - & - & - & - & - & 92 \\ \nearrow & - & 7 & - & - & - & 5 \\ \nearrow & - & - & - & 19 & 179 & 5 \\ \nearrow & 11 & 27 & 155 & 158 & 179 & 184 \\ - & 14121 & 7174 & 32547 & 5378 & 2312 & 1642 \\ - & 44 & 41 & 40 & 36 & 27 & 33\end{array}$


land species in the grassland area. It was a result of the appearance of a considerable number of seedlings and juvenile individuals of trees and shrubs, and of the enrichment of the herb layer of the following woodland species: Asarum europaeum, Carex digitata, Campanula trachelium, Hepatica nobilis, Melica nutans and Viola reichenbachiana (Table 3). The increasing importance of these groups of species was clearly visible also in the buried seed flora, and spatial distribution of their seeds was more uni- form in the year 2004 (Fig. 2). The seed participation increased both in the soil of grassland and in the brushwood zone, at the expense of grassland species. In many cases the change was highly statistically significant (Table 4). Brushwood species present here exhibit the endozoochorous (ornitochorous) mode of dispersal. The participation of ornitochores was bigger in grassland and brushwood soil in 2004, but only in the case of brushwood the increase was statistically significant.

TABLE 3. Abundance of seedlings and juvenile individuals of shrubs and trees: ++- cover between 5 and $15 \%,+$ cover less than $5 \%,--$ absence of species. Individuals lower than $50 \mathrm{~cm}$ were included into juvenile category.

\begin{tabular}{|c|c|c|c|c|c|c|}
\hline \multirow{2}{*}{ Species } & \multicolumn{2}{|c|}{ Grassland } & \multicolumn{2}{|c|}{ Brushwood } & \multicolumn{2}{|c|}{ Woodland } \\
\hline & 1999 & 2005 & 1999 & 2005 & 1999 & 2005 \\
\hline Carpinus betulus L. & - & - & + & ++ & + & ++ \\
\hline Cerasus avium (L.) Moench & - & + & - & + & - & - \\
\hline Cornus sanguinea $\mathrm{L}$. & - & ++ & + & - & + & + \\
\hline Crategus monogyna Jacq. & - & + & - & + & - & - \\
\hline Frangula alnus Mill. & - & + & - & + & - & - \\
\hline Lonicera xylosteum L. & - & + & - & - & - & + \\
\hline Prunus spinosa $\mathrm{L}$. & - & ++ & + & - & - & - \\
\hline Rhamnus cathartica $\mathrm{L}$. & - & - & - & + & - & + \\
\hline Rosa sp. & + & - & - & - & - & - \\
\hline Sorbus aucuparia L. emend. Hedl. & - & - & - & + & - & + \\
\hline Viburnum opulus L. & - & + & - & - & + & + \\
\hline
\end{tabular}

TABLE 4. Mean values of seed bank variables for three analysed plant communities ( $\mathrm{a}$ - number of seeds per square meter, $\mathrm{b}-$ participation in the total number of seeds). Differences analysed with the Wilcoxon's test. Meadow species were included into grassland group.

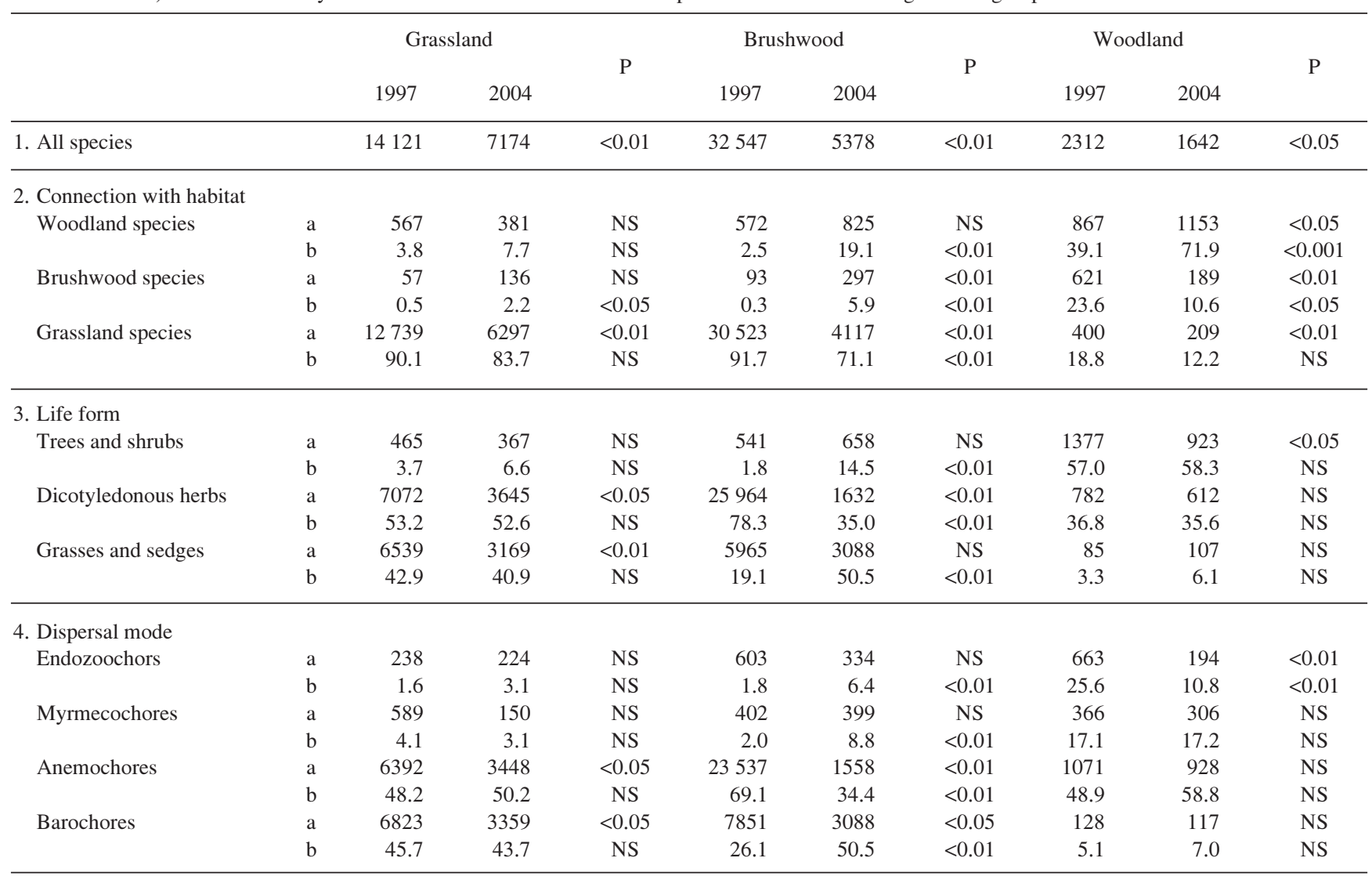

Species which were recorded in the seed bank only once (life form; dispersal mode):

Grassland: 1997 - Astragalus glycyphyllos L. (H; B), Cichorium intybus L. (H; A), Sanguisorba minor Scop. (H; B), Scrophularia nodosa L. (H; A). 2004 - Acinos arvensis (Lam.) Dandy (H. A), Aster amellus L. (H; A), Scabiosa ochroleuca L. (H; A)

Brushwood: 1997 - Erigeron annuus (L.) Pres. (H; A), Euphorbia helioscopia L. (H; M), Torilis japonica (Houtt.) DC. (H; Ep), 2004 - Cerasus avium (L.)

Moench (S; En)

Woodland: 1997 - Rumex acetosella L. (H; A), 2004 - Aruncus sylvestris Kostel. (H; A), Plantago major L. (H; A), Stellaria graminea L. (H; A) 
TABLE 5. Mean values of seed bank variables for the brushwood zone with Origanum vulgare excluded.

\begin{tabular}{|c|c|c|c|c|c|c|}
\hline & \multicolumn{2}{|c|}{ Seed number (per square meter) } & \multicolumn{4}{|c|}{ Share in the total number of seeds $(\%)$} \\
\hline & & & \multirow[t]{2}{*}{$\mathrm{P}$} & & & \multirow[t]{2}{*}{$\mathrm{P}$} \\
\hline & 1997 & 2004 & & 1997 & 2004 & \\
\hline 1. All species & 11344 & 4711 & $<0.01$ & & & \\
\hline \multicolumn{7}{|l|}{ 2. Connection with habitat } \\
\hline Woodland species & 572 & 825 & NS & 6.0 & 22.3 & $<0.01$ \\
\hline Grassland species & 9319 & 3449 & $<0.01$ & 80.5 & 66.2 & $<0.01$ \\
\hline \multicolumn{7}{|l|}{ 3. Life form } \\
\hline Trees and shrubs & 541 & 658 & NS & 4.4 & 16.7 & $<0.01$ \\
\hline Dicotyledonous herbs & 4760 & 964 & $<0.01$ & 50.9 & 26.3 & $<0.01$ \\
\hline Grasses and sedges & 5965 & 3088 & NS & 42.9 & 57.0 & $<0.05$ \\
\hline Endozoochors & 603 & 334 & NS & 5.3 & 7.5 & NS \\
\hline Myrmecochores & 402 & 399 & NS & 4.7 & 10.5 & $<0.05$ \\
\hline Anemochores & 2334 & 890 & $<0.01$ & 23.4 & 24.9 & NS \\
\hline Barochores & 7851 & 3088 & $<0.05$ & 64.3 & 57.1 & NS \\
\hline
\end{tabular}

The seed bank of the brushwood zone in 1997 was dominated by Origanum vulgare (21 204 seeds $-65 \%$ of the total number of seeds) and till 2005 the number of diaspores of this species decreased significantly (668 seeds; $12 \%)$. It might suggest that this species is mainly responsible for the changes in the structure of the seed bank. How-

TABLE 6. Mean number of seeds and species (per square meter) in three adjacent plant communities. Differences analysed with the Kruskal-Wallis test.

\begin{tabular}{ccccc}
\hline & Grassland & Brushwood & Woodland & P \\
\hline $\begin{array}{l}\text { Seed number } \\
1997\end{array}$ & 14121 & 32547 & 2312 & $<0.0001$ \\
2004 & 7174 & 5378 & 1642 & $<0.05$ \\
\hline $\begin{array}{l}\text { Species number } \\
1997\end{array}$ & 11.8 & 12.5 & 6.4 & $<0.0001$ \\
2004 & 11.5 & 11.8 & 7.8 & $<0.001$ \\
\hline
\end{tabular}

ever, when Origanum vulgare was excluded, the effects of the analyses did not change significantly (Table 5).

Seed number seems to decrease during succession in the analysed arrangement of plant communities. This tendency is clear when we take into consideration changes in time (chronosequence; Table 4) and differences in the total number of seeds in soil of plant communities representing three successional stages at the same time (toposequence, Table 6). The total number of species did not change in the most dynamic plant communities: the grassland and brushwood ones, and it is significantly higher there than in the seed bank of woodland (Tables 6 and 7). However, the amount of grassland species in grassland and brushwood soil decreased and they were replaced by woodland and brushwood species. Differences in the case of the brushwood zone were statistically significant.

The Detrended Correspondence Analysis (DCA) showed that seed banks of studied plant communities were more similar to each other than surface vegetation (Fig. 3). The

TABLE 7. Mean number (per square meter) of species with various features in three adjacent plant communities. Differences analysed with the Wilcoxon's test.

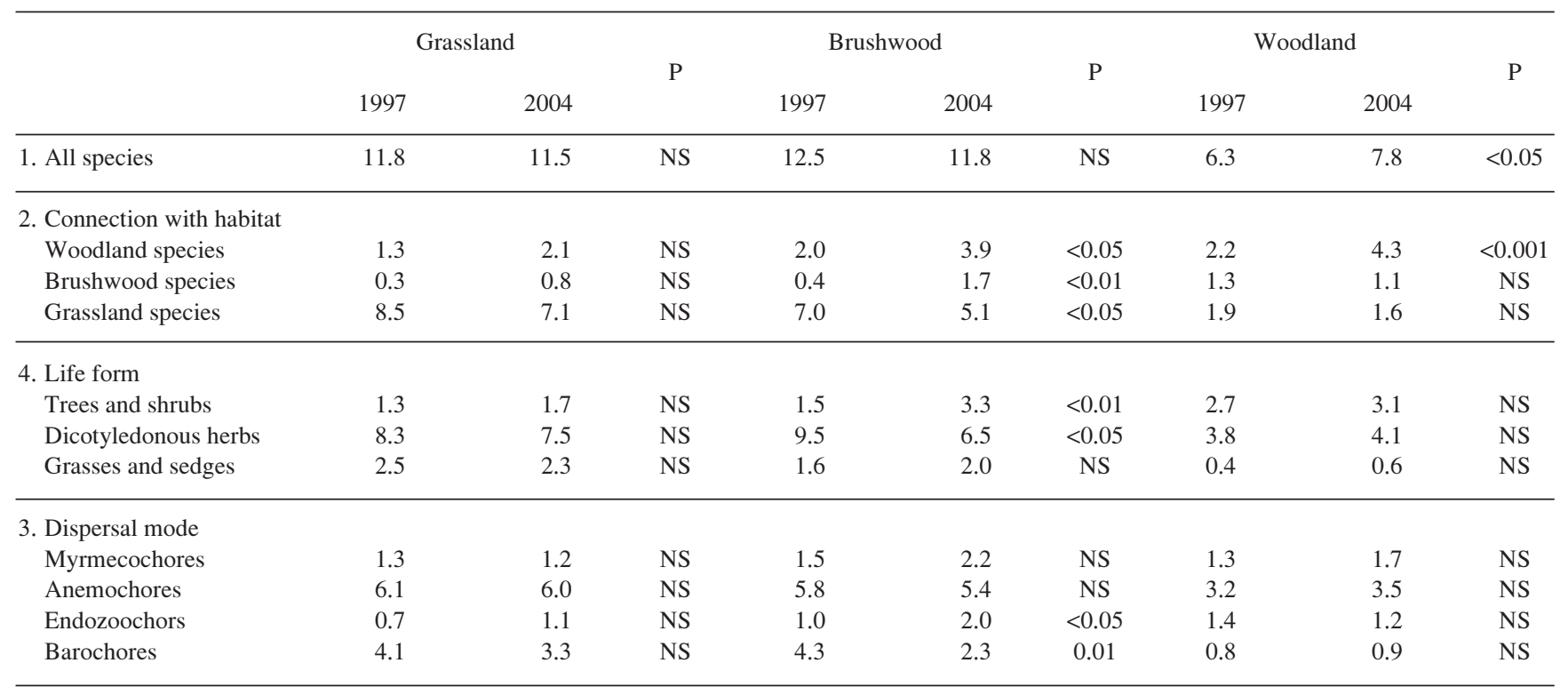




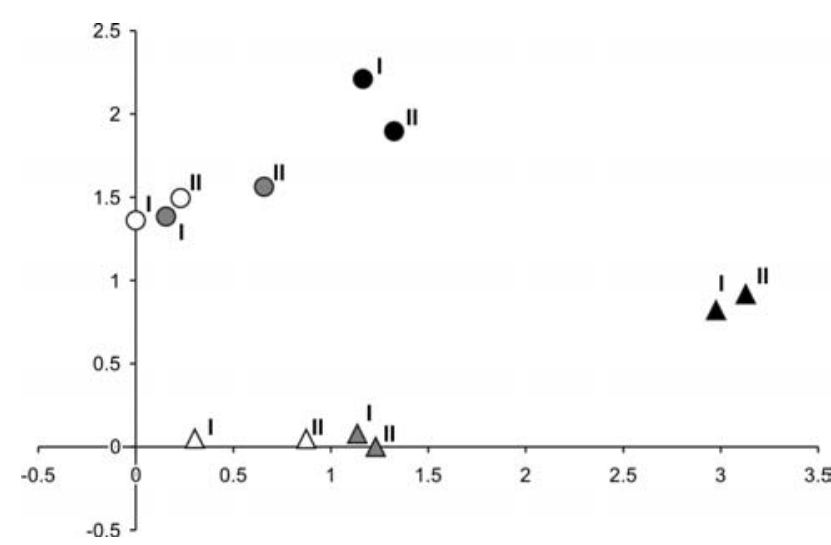

Fig. 3. Detrended Correspondence Analysis (DCA) of surface vegetation and seed bank data. Circles - seed bank, triangles - vegetation; white colour - grassland, grey - brushwood, black - woodland; I - data from the first season of observation, II - data from the second season of observation.

first axis divides sampling sites according to the successional gradient in the case of vegetation and seed bank data as well. The other axis separates seed bank and vegetation data. Seed bank, as well as the vegetation of grassland and brushwood, are quite similar. The most important quantitative and qualitative changes in seven years interval took place in the grassland vegetation. It is much more similar to brushwood vegetation now, than it was in 1997.

\section{DISCUSSION}

Falińska (1999) suggests different patterns of changes of the seed bank which can be realised during succession: directional changes (the increase or decrease of seed number), fluctuations (pattern observed during the succession on abandoned meadows) and fluctuation-lottery. The conclusions that the species richness in the soil seed bank and the density of buried seeds decline during succession were formulated on the basis of observation of old field succession and succession in deciduous forests (Symonides 1986; Pickett and McDonell 1989). In the case of brushwood encroachment on xerothermic grasslands, they were confirmed in the present study and in the study of Bakker et all. (1996), but the observation kept by Milberg (1995) and Kalamees and Zobel (1997) gave completely different results. According to Milberg (1995), the 18-year-period of his observation was not long enough to allow vegetation changes to proceed to the point that long-term trends would become detectable. In my study the period taken under consideration was much shorter and I realise that only further observations will enable me to confirm or reject both hypotheses in the case of the grasslands of the White Mountain.

In order to understand ecological succession it seems important to determine factors which affect seed dispersal, deposition and recruitment of seedlings. In the case of grassland communities birds may have a significant influence on the course of succession (McClanahan and Wolfe 1987; Adamowski and Knopik 1996; Loster and Gawroński 2005). The appearance of even a small number of ornitochorous seeds and their seedlings can be treated as a signal that the bush encroachment will accelerate. In the Białowieża experimental garden the first seedlings of orni- tochores appeared after 13 years of abandonment and then quickly grew in numbers (Adamowski and Knopik 1996). The maximum density of seedlings of ornitochores is usually observed under the canopy of isolated trees and shrubs (so called "nucleation process") - the favourite perching places for dispersers. This explains why the mechanism of dispersal is the most significant in the central stages of succession, after the stage of open grassland and before the dense forest stage (Debussche and Isenmann 1994). Bushes modify the microclimate and reduce competition of grasses and herbs - a decrease of herb layer (which was also observed in the present study) enables the establishment of seedlings of brushwood and woodland species (Debussche and Isenmann 1994; Adamowski and Knopik 1996).

Secondary succession is usually slower in drier grasslands due to droughts which prevent growth and kill newly established plants (Milberg and Hansson 1994). In the studied area I observed much more seedlings in shaded parts of the grassland (seedlings of the brushwood and woodland species, e.g. Cornus sanguinea, Carpinus betulus and Hepatica nobilis, were also present there). In unshaded parts few seedlings grouped in small microhollows and under the leaves of adult plants (Czarnecka J. 2004b). The lack of places of safe germination because of the stress connected with insufficient water supply is probably the main reason of slower succession process in other parts of the grassland situated in the south-western parts of the White Mountain.

\section{LITERATURE CITED}

ADAMOWSKI W., KNOPIK A. 1996. Ornitochorous species penetration onto abandoned farmland during secondary succession. Phytocoenosis 8 (N. S.) Sem. Geobot. 4: 97-110.

BABCZYŃSKA-SENDEK B. 2004. Zagrożenia oraz przemiany roślinności kserotermicznej na obszarze Wyżyny Śląskiej. In: Przyroda Polski w europejskim dziedzictwie dóbr natury. Streszczenie referatów i plakatów. Jendrzejczak E. (ed.), Polskie Towarzystwo Botaniczne, Oddział Bydgoski, Oddział Toruński, Wydawnictwa Uczelniane ATR w Bydgoszczy, Toruń-Bydgoszcz, pp. 58. (in Polish)

BAKKER J.P., BAKKER E.S., ROSÉN E., VERWEIJ G.L., BEKKER R.M. 1996. Soil seed bank composition along a gradient from dry alvar grassland to Juniperus shrubland. J. Veg. Sci. 7: 165-176.

BĄA W. 2003. Changes in the structure and floristic composition of the limestone grasslands after cutting trees and shrubs and mowing. Acta Soc. Bot. Pol. 72 (1): 61-69.

BOBBINK R., WILLEMS J.H. 1987. Increasing dominance of Brachypodium pinnatum (L.) Beauv. in chalk grasslands. Biol. Conserv. 40: 301-314.

CZARNECKA B. 1994. Zbiorowiska Białej Góry koło Tomaszowa Lubelskiego jako siedlisko rzadkich roślin naczyniowych (Plant communities of the White Mountain as the place of occurrence of rare vascular plants). Chrońmy Przyr. Ojcz. 50 (2): 16-22. (in Polish)

CZARNECKA B. 1995. Biologia i ekologia izolowanych populacji Senecio rivularis (Waldst. et Kit.) DC. i Senecio umbrosus Waldst. et Kit. (Biology and Ecology of the Isolated Population of Senecio rivularis (Waldst. et Kit.) DC. and Senecio umbrosus Waldst. et Kit.). Wyd. UMCS, Lublin. (in Polish)

CZARNECKA J. 2004a. Microspatial structure of the seed bank of xerothermic grassland - intracommunity differentation. Acta Soc. Bot. Pol. 73 (2): 155-164. 
CZARNECKA J. 2004b. Seed longevity and recruitment of seedlings in xerothermic grassland. Pol. J. Ecol. 52 (4): 505-521.

CZARNECKA J. 2005. Seed dispersal effectiveness in three adjacent plant communities; xerothermic grassland, brushwood and woodland. Ann. Bot. Fenn. 42 (3): 161-171.

CZARNECKA J., CZARNECKA B. 2001. The role of a seed bank in the maintenance of valuable components of xerothermic grassland. Ekológia (Bratislava) 20, Suppl. 4: 215-221.

DEBUSSCHE M., ISENMANN P. 1994. Bird dispersed seed rain and seedling establishment in patchy Mediterranean vegetation. Oikos 69: 414-426.

DZWONKO Z. 2001. Migration of vascular plant species to a recent wood adjoining ancient woodland. Acta Soc. Bot. Pol. 70 (1): 71-77.

DZWONKO Z., LOSTER S. 1992. Zróżnicowanie roślinności i wtórna sukcesja w murawowo-leśnym rezerwacie Skołczanka koło Krakowa (Vegetation differentiation and secondary succession in the Skołczanka grassland-forest reserve near Kraków, Southern Poland). Ochrona Przyrody 50 (1): 33-64. (in Polish)

DZWONKO Z., LOSTER S. 1998. Dynamics of species richness and composition in a limestone grassland restored after tree cutting. J. Veg. Sci. 9: 387-394.

FALIŃSKA K. 1999. Seed bank dynamics in abandoned meadows during a 20-year period in the Białowieża National Park. J. Ecol. 87 (3): 461-475.

GRANDIN U., RYDIN H. 1998. Attributes of the seed bank after a century of primary succession on islands in Lake Hjalmaren, Sweden. J. Ecol. 86 (2): 293-303.

HURST A., JOHN E. 1998. The biotic and abiotic changes associated with Brachypodium pinnatum dominance in chalk grassland in South-East England. Biol. Conserv. 88: 75-84.

HYATT L.A., CASPER B.B. 2000. Seed bank formation during early secondary succession in a temperate deciduous forest. J. Ecol. 88 (3): 516-527.

KALAMEES R., ZOBEL M. 1997. The seed bank in an Estonian calcareous grassland: comparison of different successional stages. Folia Geobot. Phytotax. 32: 1-14.

KALAMEES R., ZOBEL M. 2002. The role of the seed bank in gap regeneration in a calcareous grassland community. Ecology 83 (4): 1017-1025.

KULPA W. 1974. Nasienioznawstwo chwastów. PWRiL, Warszawa. (in Polish)

LOSTER S., GAWROŃSKI S. 2005. Przemiany nawapiennej murawy w rezerwacie "Biała Góra" (Wyżyna Miechowska, południowa Polska) w ciągu ostatnich 80 lat. (Changes in a calccareous grassland in the reserve "Biała Góra" (Miechowska Upland, S Poland) during the last 80 years). Fragm. Flor. Geobot. Polonica 12 (2): 301-315. (in Polish)

MCCLANAHAN T.R., WOLFE R.W. 1987. Dispersal of ornithochorous seeds from forest edges in central Florida. Vegetatio 71: 107-112.
MILBERG P. 1992. Seed bank in a 35-year-old experiment with different treatments of a semi-natural grassland. Acta Oecol. 13: 743-752.

MILBERG P. 1993. Seed bank and seedling emerging after disturbance in a wet semi-natural grassland in Sweden. Ann. Bot. Fenn. 30: 9-13.

MILBERG P. 1995. Soil seed bank after eighteen years of succession from grassland to forest. Oikos 72: 3-13.

MILBERG P., HANSSON M.L. 1994. Soil seed bank and species turnover in a limestone grassland. J. Veg. Sci. 5: 35-42.

PICKETT S.T.A. 1989. Space for time substitution as an alternative to longterm studies. In: Long-term studies in ecology. Approaches and alternatives. Likens G.E. (ed.), Springer, New York, pp. 110-135.

PICKETT S.T.A., MCDONELL M.J. 1989. Seed bank dynamics in temperate deciduous forests. In: Ecology of soil seed banks. Leck M.A., Parker V.T., Simpson R.L. (eds), Academic Press, San Diego, CA, pp. 123-147.

POSCHOLD P., WALLISDEVRIES M.F. 2002. The historical and socioeconomical perspective of calcareous grasslands lessons from the distant and recent past. Biol. Conserv. 104: 361-376.

RUSH G., VAN DER MAAREL E. 1992. Species turnover and seedling recruitment in limestone grasslands. Oikos 63: 139$-146$.

SCHENKEVELD A.J., VERKAAR H.J. 1984. The ecology of short lived forbs in chalk grasslands: distribution of germinative seeds and its significance for seedling emergence. J. Biogeogr. 11: 251-260.

SCHLAEPFER F. 1997. Influence of management on cover and seed production of Brachypodium pinnatum (L.) Beauv. in calcareous grassland. Bulletin of the Geobotanical Institute ETH: 3-10.

SKRZYPCZAK G., BLECHNARCZYK A., SWĘDRZYŃSKI A. 1997. Podręczny atlas chwastów. Wyd. Medix Plus, Poznań (in Polish)

SYMONIDES E. 1986. Seed bank in old-field successional ecosystems. Ekol. Pol. 34 (1): 3-29.

TER BRAAK C.J.F., SMILAUER P. 2002. CANOCO Reference Manual and CanoDraw for Windows User's guide. Software for Canonical Community Ordination (version 4.5). Microcomputer Power, Ithaca, NY, USA.

THOMPSON K. 1986. Small scale heterogenity in the seed bank of an acidic grassland. J. Ecol. 74 (3): 733-738.

WALLISDEVRIES M.F., POSCHOLD P., WILLEMS J.H. 2002. Challenges for conservation of calcareous grasslands in northwestern Europe: integrating the requirements of flora and fauna. Biol. Conserv. 104: 265-273.

WILLEMS J.H. 1983. Species composition and above ground phytomass in chalk grassland with different management. Vegetatio 52: 171-180. 